\title{
INNOVATIVE PROCESSES WITHIN COMMUNICATION AND MOTIVATION, WORK ENVIRONMENT CARE AND CREATIVITY SUPPORT OF HUMAN RESOURCES
}

\author{
Zuzana Lušňáková1 ${ }^{1}$ Silvia Lenčéšováㄹ, Veronika Hrdá1, Mária Šajbidorová1 \\ ${ }^{1}$ Department of Management, Faculty of Economics and Management, Slovak University of Agriculture in Nitra, \\ Tr. A. Hlinku 2, 94976 Nitra, Slovak Republic
}

Link to this article: https://doi.org/10.11118/actaun202068020395

Received: 24. 10. 2019, Accepted: 31. 3. 2020

To cite this article: LUŠŇÁKOVÁ ZUZANA, LENČÉŠOVÁ SILVIA, HRDÁ VERONIKA, ŠAJBIDOROVÁ MÁRIA. 2020. Innovative Processes Within Communication and Motivation, Work Environment Care and Creativity Support of Human Resources. Acta Universitatis Agriculturae et Silviculturae Mendelianae Brunensis, 68(2): 395-405.

\begin{abstract}
The given issue applied in the practise of food businesses in Slovakia is very actual. The objective reason is especially the fact that the food businesses are producers of domestic foodstuffs, production of which is considered very important not only from nutritional point of view for the population and availability of quality domestic products but from sustainability of employment in this branch, development and application of quality, qualified and committed employees, point of view as well. The objective of the paper is to find out how food businesses working in Slovakia implement and use new trends, in selected areas of human resource management, in reality. The research actively included 453 food businesses from all the Slovakia. The statistical relations and correlations between variables were performed by Cronbach alpha, Spearman test, Kruskal-Walis test using programs EXCEL and SAS Enterprise Guide 7.1. We found out that food businesses in Slovakia show significant reserves and shortcomings in a practical application of new trends within human resource management despite of the fact that their representatives realize the importance of human resources. In the conclusion, we provide suggestions and recommendations to improve the company practise.

Keywords: communication, motivation, creativity support, work environment, human resource management, new trends
\end{abstract}

\section{INTRODUCTION}

Nowadays, in faster and more active world of economic, political, technological and social changes influencing business, every organization, which wants to be successful on the market, must adjust to changes.

As well as in the other areas of management, in human resource management there are changes and new processes. New trends emerge, which have various usage and impact on employees, managers and companies. Amongst the factors influencing development and state of human resources and human potential in the organization belong knowledge and experience, creativity of employees and their ability to create and innovate, flexibility, education and development, motivation and satisfaction. A manager is a leader who motivates by explaining causes and impacts of employees' acting acting and provides feedback and at the same time they try to preserve work-life balance of their subordinates. Young generation of employees is determined to work on themselves, be loyal to the society. Inevitable part is commitment of employees within more demanding and interesting tasks, with an importance of adequate evaluation and benefits for creativity, work and loyalty. 
If we want that the company employes skilled people, they must be offered more - participation at the decision-making, transfer of competences and so forth. They will not be convinced by phrases in company materials, the owner must be an example every day. Strictly introduced motivation in accordance with goals can decide whether the company attracts the best candidates and whether they remain in the team. Directive approach is nowadays left behind or it is used only in critical situations.

\section{Theoretical Background}

Communication and motivation of employees are two crucial and irrecoverable areas of human resource management. Communication might also be a basic pillar of a working organization. Organization is working due to collective activity of people, even though every individual is different and able to act separately. To reach coordinated results, a goodworking communication is important (Szarková, 2018).

Communication competences or communication skills are the basis for performing quality work. Communication skills can be divided into general, which create the basis for all the other skills, special, including empathy, assertiveness, effective listening, feedback and motivation ability (Poláček, 2016). To motivate employees means to understand circumstances which enable motivation as well as circumstances which unable it. These circumstances are generally named as motivational factors. Their common feature is that they either satisfy human needs or they unable their satisfaction.

The $21^{\text {st }}$ century provides various methods classical as well as modern which ensure the right set of internal communication strategy. Anyway, it is a task of the organization to consider which tool should be used for a specific situation. It is necessary to communicate in a way that the selected information is understandable and interesting for the target group (Ruck, 2015).

A present trend of employees' motivation comes out from a different approach to new generation, of which priorities, work attitude and motivational factor have changed in comparison with middle or even older generation. Employees or candidates who are a part of young generation, are technologically skilled, they can work with information. They are team oriented, they have a contact database and they build global relationships. They are goal-oriented rather than process-oriented, on how to reach the result. It is natural for them to perform more tasks at once (multitasking) and they prefer antidiscrimination with a respect to diversity and human rights. Young generation of employees should try to protect their identity and privacy and at the same time to respect privacy of others - colleagues, supervisors, business partners, customers.
Work environment is a significant factor influencing employees. Work-life balance represents coordination of professional life with personal life. To align professional and family life nowadays represents an ideal equation of human life, as quality of personal life has a significant influence on work performance itself and increased work performance. Work - life balance came into using especially for mothers who have a part-time job because they care about children. Anyway, this expression is not determined only for mothers, but for fathers and grandparents and others who work and take care of a family member, excluding their age (Šimonová and Šafránková, 2015). It represent harmonization of professional and non-professional life, whereas it interferes almost every area of each employee's life (Adame-Sánchez, González-Cruz, Martínez-Fuentes, 2016). A company decision to implement this modern trend however depends on how the company perceives its advantages. Relax zones are becoming very favourite amongst modern employers. They are often used by employees and positively influence their work performance. Modern organizations seek creativity of their employees but motivation for creativity in unfavourable work conditions, bad work environment and high work pressure is very demanding (Shao, Nijstad, Tauber, 2019).

\section{MATERIALS AND METHODS}

The objective of the paper is to evaluate implementation of new trends in human resource management through quality of internal communication, systematic motivation, improved work environment and creativity support of employees. Within practical realization we focused on findings in using new trends in human resource management in food businesses in Slovakia.

Primary research was focused on activities within human resources in food businesses working in Slovakia. Based on data available on the web page of Statistical Office of the Slovak Republic, in the first quarter of 2019 there were 587988 economic subjects in Slovakia. Out of which 4434 subjects were working, according to the statistical classification of economic activities SK NACE, in the sector of CA "Food, beverages and tobacco production". Even though the given number represents only $0.75 \%$ share of all the economic subjects, food businesses in Slovakia are an important part of national economy and they significantly influence production of domestic foodstuffs and beverages and at the same time they provide work positions for population.

A questionnaire called "New trends in human resource management in food businesses" was created based on elaborated theoretical results. The first part was identification questions such as a size of a company, legal form, capital share of the company and the region of Slovakia in which the 
company operates. Each area contained several questions and thanks to specific statements we found out whether a specific activity within human resources is performed by the companies. We also searched how new trend in individual parts of business are implemented. Positive, rather positive, neutral, rather negative or negative attitude to question was expressed on a five-level Likert scale.

The questionnaire was, within pilot research in February 2019, tested on a sample of 20 companies in the Nitra region. After little modification, the final research was done from March to April 2019, the questionnaire was provided by a phone call arrangement or e-mail arrangement to $470 \mathrm{food}$ businesses operating in Slovakia. The respondents who answered the questions, were managers from human resource departments. In case that the organization did not have separated department for human resources, the questionnaire was filled in by the manager or the owner, responsible for this area. By the beginning of May 2019 we received electronic or a printed version of 453 filled questionnaires ready for use, elaboration and evaluation.

The research included 70 big, 125 middle, 148 small and 110 micro companies. From the organizationallegal business form point of view we focused exclusively on companies which are incorporated (160) or limited (293) because there are various businesses with various organizational-legal business forms in Slovakia a to control assumptions we wanted to ensure representativeness of a selection file as for the organizational-legal business forms. The research included 379 exclusively Slovak businesses, 35 exclusively foreign businesses and 39 businesses with a combined capital share. As for the territorial point of view, there were food businesses from all the eight regions of Slovakia.

The questionnaire's answers were elaborated and classified which enabled consequent verification of the given research assumptions by selected mathematical-statistical methods and formulation of suggestions and recommendation for the practice.

In order to evaluate the level of active work with human resources in food businesses operating in Slovakia and implementation of new trends within human resource management we formulated and, based on realized analysis, verified the following research assumptions:

- Communication and motivation

A1: We suppose that the companies which perceive communication as an inevitable assumption of mutual cooperation in a company and outside the company, have strictly set rules for employees' motivation.

- Creativity and work environment

A2: We suppose that the companies supporting creativity of employees pay adequate attention to work environment and apply work-life balance principles.

\section{Characteristics and Reason of the Selected Mathematical-statistical Methods Application}

Processing the data, obtained by the questionnaire, was done through table processor MS EXCEL 2016. The data was evaluated through statistical software SAS Enterprise Guide 7.1.

The consistency of a selection file was found by Cronbach alpha coefficient. Cronbach alpha coefficient belongs to widely used methods of scale reliability evaluation and represents level of the internal consistency. If Cronbach alpha coefficient reaches values of 0.7 and more, it represents sufficient internal scale consistency (BendaProkeinová, 2014).

From the data obtained from the questionnaire, where respondents had a possibility to express the level of approval or disapproval with the statement on a five-level Likert scale, we found the characteristics of a position. According to Prokeinová (2010), through application of basic descriptive characteristics we gain values of modus and averages of individual respondents' preferences.

In the next part of the research we applied correlation analysis. Correlation analysis represents, according to Benda-Prokeinová (2014), statistical approach which describes a relationship between numeral variables. The more the absolute value of correlation coefficient reaches one, the stronger the dependence and vice versa, the more it reaches zero, the weaker the dependence.

For testing statistical hypothesis resulting from research assumptions, mathematical-statistical methods - non parametrical test were applied: Kruskal-Wallis test and Spearman coefficient. We searched for differences in answers of the questionnaire based on specific identification symbols, dependence between two variables, as well as the power of this dependence (Markechová, Stehlíková, Tirpáková, 2011; Rimarčík, 2007).

Except for the questionnaire, we realized managed structured interviews in selected food businesses from February to March, providing us with the entrance to the issue of human resources and enabled us with quality analysis of the given issue from a different point of view, even though the answers of the respondents can be considered as partially subjective. Nevertheless, we used the method of observation, findings of which were a contribution for a discussion, formulation of suggestions and recommendations and making conclusions.

\section{RESULTS}

As new technologies emerge, a professional life changes as well. New generations of employees come to work and they require change of work environment in which people will work. It manifests in benefits offered by companies and in a number of people working separately. Even work 
environment must adjust to changes. Especially in case that companies want executive and productive employees, who are happy to go to work. Companies must react to these changes if they want to keep and attract talents of new generation. If they have pleasant work environment, they will be happy at work. Due to this fact they will communicate better, cooperate more effectively and moreover they will be able to live healthy life. And therefore their productivity will rise, which will manifest in the company's results.

Within selected issue, which we consider highly actual, we paid attention to analysis and evaluation of facts, gained by realization of the questionnaire in food businesses in Slovakia.

The questionnaire contained statements, approved or disapproved by the respondents (management members of selected companies) on a five-level Likert scale. Due to application of five-level Likert scale it was inevitable to test sufficiency of its internal consistency. The value of Cronbach Alfa reached the level of 0.833025, which represents sufficient internal scale consistency. Based on the given fact we used the next analysis.

I: Cronbach Alpha coefficient

\begin{tabular}{lc}
\hline \multicolumn{2}{c}{ Cronbach Coefficient Alpha } \\
\hline \multicolumn{1}{c}{ Variables } & Alpha \\
\hline Raw & 0.837452 \\
Standardized & 0.833025 \\
\hline
\end{tabular}

Source: owned elaboration

\section{Communication and Motivation}

At present, the task of managers is to regulate employees to independence and responsibility for their work. Present trend of communication through ICT is a threat in the area of confounding simple activities like correctly written formal letter or face to face communication. Providing education and training of personal and professional development can be interesting motivation factors, together with high probability of removal of shortcomings (Koubek, 2007).

The first section of questions, which was most abundant as for the number of questions, we researched how companies perceive communication and motivation in the company and whether they follow the newest trends in communication and motivation of employees. Within the first five questions respondents expressed their opinion about communication on a workplace and about forms they use. The second part of penultimate section contained four questions connected with motivation, forms of motivation and stimulus of employees in the company.

Average and most common answers to above mentioned questions are graphically shown in the Fig. 1. The bar graph shows average answers of respondents (data is shown in the basis of the graph) and the line graph shows the most common answers of respondents (data is shown above the graph).

The highest value expressing level of approval with statement was reached by statement "Communication is inevitable and important attribute of mutual cooperation in a company and outsid". The value of average answer was 4.7 and respondents often marked option " 5 - I absolutely agree". Up to $85.21 \%$ of respondents who were asked, expressed that they absolutely agree with this statement. On the other hand, only 3.31\% of respondents did not agree with the statement.

The following statement, which gained the second highest level of approval within our research, was: "In the company, we prefer personal communication to communication through media (face-to-face, meetings, formal or informal meeting, etc.)". The average answer reached value of 4.51 and the most common value marked was 5, which represented absolute approval with the statement. The statement was absolutely approved by $68.87 \%$ of representatives of the food businesses and absolutely disapproved by $3.09 \%$.

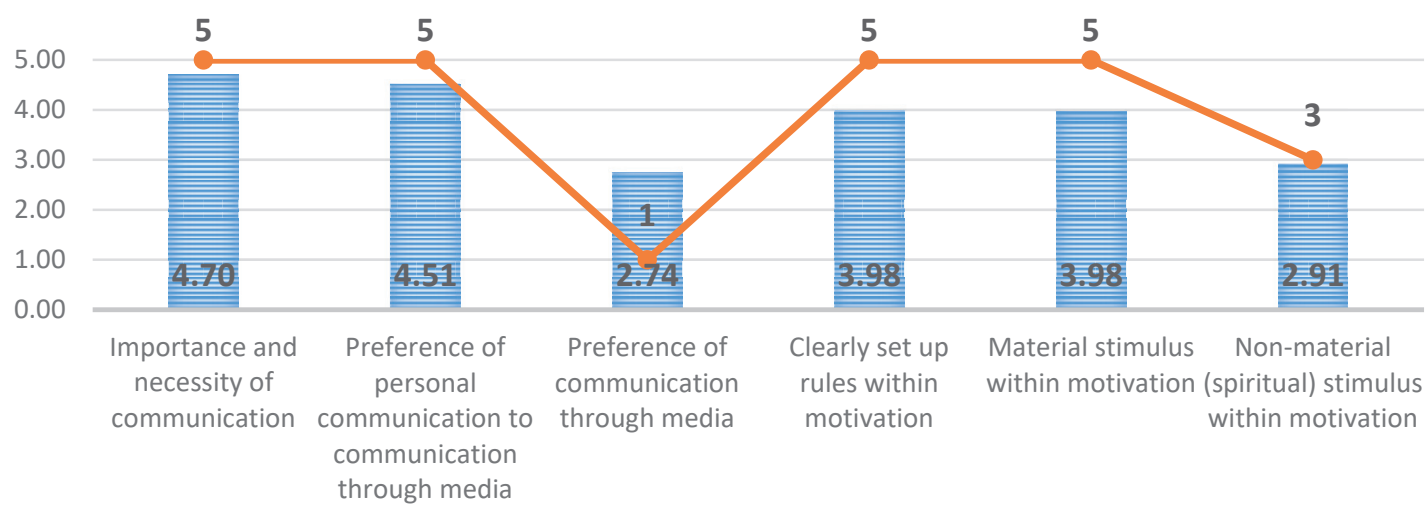

average $\longrightarrow$ modus

1: Characteristics of position evaluating communication and motivation Source: own elaboration 
The average value of the answer expressing level of approval with the statement "Within communication in the company we prefer communication through media (social networks, applications, mail etc.)" was 2.74. The most common answer was "I absolutely do not agree (1)" and this answer was expressed by $27.37 \%$ of respondents from food businesses in Slovakia. Absolute approval was expressed by only $13.25 \%$ of respondents.

The most common answer to the statement "Motivation of employees is realized based on strictly given rules" was "I absolutely agree" and there was 39.07\% of respondents. The average answer reached value of 3.98 (I partially agree). Only 1.99\% of managers absolutely agreed with the statement.

The same as the previous statement, the statement "Motivation of employees is realized by material stimulus (financial benefits...)" mostly got the answer with value of 5 and average answer was 3.98. 37.31\% of respondents absolutely agreed and only $3.31 \%$ expressed that they absolutely do not agree with the given statement. The statement's "Within motivation of employees we use especially non material (spiritual) stimulus" most common answer was neutral (3), answered by $36.42 \%$ of respondents. Even an average answer had a value of 2.91 expressing neutral attitude. The statement was absolutely approved by $8.61 \%$ of company representatives and absolutely disapproved by $12.36 \%$

Within the issue of communication and motivation we asked respondents question with the possibility of selection of more answers. Personal interview face-to-face was selected by respondents as the most common form of personal communication in the company (87.9\%), meetings were selected by $59.1 \%$ of respondents. Formal meetings got the answer from $12.9 \%$ of respondents and informal meetings were selected by $17.4 \%$ of respondents.

Percentage share of answer to a question "Which form of the media communication is mostly used in the company", where respondents could select more answers, is as follows: Chat is used by $7.6 \%$ of companies, Intranet 15.2\%, Facebook 26.5\%, Instagram 3.8\%, Messenger 21.2\%, Viber 9.8\% and the biggest share within the answers was e-mail $(65.2 \%)$

We asked the managers of the companies, which of the spiritual forms of stimulation are used in the company often. The answer was a praise, receiving the highest number of answer from respondents and it was selected by $86.4 \%$ of them. Recognition manifests within $43.9 \%$ of company employees. The possibility of a career development within motivation provides 18.8\% companies. Graduation received $16.7 \%$ and support of education within motivation was selected by $12.9 \%$ companies.

Application of Kruskal-Wallis test showed existence of statistically significant differences between answers of respondents based on identification symbols of companies - their size, legal form of business, capital share or region, in which they operate. The results are presented in the Tab. II. The values marked “*” represent statistically significant differences on the significance level of 95\% $(\alpha=0.05)$ and values marked “**” represent highly statistically significant differences on a significance level 99\% ( $\alpha=0.01)$.

Based on realized Kruskal-Wallis test we can state that in case of importance and necessity of communication, there are statistically significant differences in the answers of companies only based on size of companies. That means that legal form of business, company capital share nor region in which the company operates, do not consider communication as important and necessary attribute of mutual cooperation in the company or outside. One of the reasons of non-existence of differences in the answers of representatives of companies, is the fact that more than $85 \%$ of companies consider communication as inevitable.

To preference of personal communication to communication through media has influence on region where the company operates. Within this factor, there is value of 0.0119 , which is lower than $a=0.05$, which means that in this case there are statistically significant differences in the answers.

II: Results of Kruskal-Wallis test-communication and motivation of employees

\begin{tabular}{|c|c|c|c|c|}
\hline & \multicolumn{4}{|c|}{ Values of Kruskal-Wallis test according to } \\
\hline & $\begin{array}{c}\text { Size } \\
\text { of company }\end{array}$ & $\begin{array}{l}\text { Legal form } \\
\text { of business }\end{array}$ & $\begin{array}{l}\text { Capital share } \\
\text { of company }\end{array}$ & Region \\
\hline Importance and necessity of communication & $0.0079 * *$ & 0.4635 & 0.3403 & 0.2324 \\
\hline $\begin{array}{l}\text { Preference of personal communication } \\
\text { to communication through media }\end{array}$ & 0.4146 & 0.0987 & 0.1094 & $0.0119 *$ \\
\hline Preference of communication through media & $0.0002^{* *}$ & $0.0044^{* *}$ & $<0.0001^{* *}$ & 0.1081 \\
\hline Strictly set rules within motivation & $0.0002^{* *}$ & 0.7975 & $0.0394^{*}$ & $<0.0001^{* *}$ \\
\hline Material stimulus within motivation & $0.0378^{*}$ & 0.2256 & 0.1218 & 0.0052 \\
\hline Non material (spiritual) stimulus within motivation & $0.0243^{*}$ & 0.3212 & $0.0233^{*}$ & $0.0047 * *$ \\
\hline
\end{tabular}

Source: own elaboration 
Size of company, legal form of business nor capital share do not influence preference of personal communication to communication through media.

On the contrary, in the case of preference of communication through media there are highly statistically significant differences even according to size of company, legal form of business as well as capital share on the significance level of 99\%. Only region where the company operates does not have influence on preference of communication through media.

Application of motivation based on strictly set rules is influenced by size of company, region where the company operates and capital share of company as well. The existence of differences was confirmed on the significance level $\alpha=99 \%$ or $95 \%$. Legal form of business does not influence strictly set rules within motivation.

Using material stimulus within motivation is influenced only by size of company. The found value of coefficient is 0.0378 . There are statistically significant differences in the answers on the significance level of $a=0.05$. The remaining three factors do not influence using material stimulus within motivation of employees.

In the case of using non-material stimulus within motivation there are statistically significant differences on the significance level of 95\% depending on size of company and capital share of company and highly statistically significant differences on the significance level of $99 \%$ as for the region where the company operates. It means that size of company, capital share of business and region where the company operates influence using non-material stimulus within motivation of employees and legal form of business does not have influence.

Spearman correlation coefficient showed the power of dependence between individual answers of respondents. The highest value of dependence is 0.53292 and it is highly statistically significant. It represents an important and very strong positive dependence between preference of communication through media and using material stimulus within motivation. We then found out three highly statistically significant low to medium positive dependences, one statistically significant trivial or no dependence, 5 statistically insignificant positive dependences. We will find three negative dependences, out of which two are not statistically significant. One statistically significant dependence represents negative dependence between preference of personal communication to communication through media in the company. The last negative correlation is very logical because those are statements which eliminate each other.

Medium to essential positive dependence was found even within preference of communication through media and active support of creativity of employees. The highest negative dependence has a value of -0.17856 and it is highly statistically significant. It represents low to medium negative dependence between preference of personal communication to communication through media and providing opportunities to work in international teams. Interpretation is as follows: if company prefers personal communication, employees are not provided with a possibility to work in international teams. The given statement is approved by other values of correlation coefficients.

\section{Creativity and Work Environment}

Work environment significantly influences work performance of employees as well as their creativity and commitment. Speaking of connection between employee and work environment, there are factors which directly or indirectly influence employee. Properly set up work environment, which significantly takes into account needs and imagination of employees can be, in the end, positive contribution in many areas of the company especially speaking of mid-term and long-term horizon (Pindrochova, 2015).

Creative thinking expresses attitude to issues and solutions, it represents about their ability to connect existing thoughts into new combinations. The skill itself depends on personality as well as on what the person thinks and how they work. Creativity

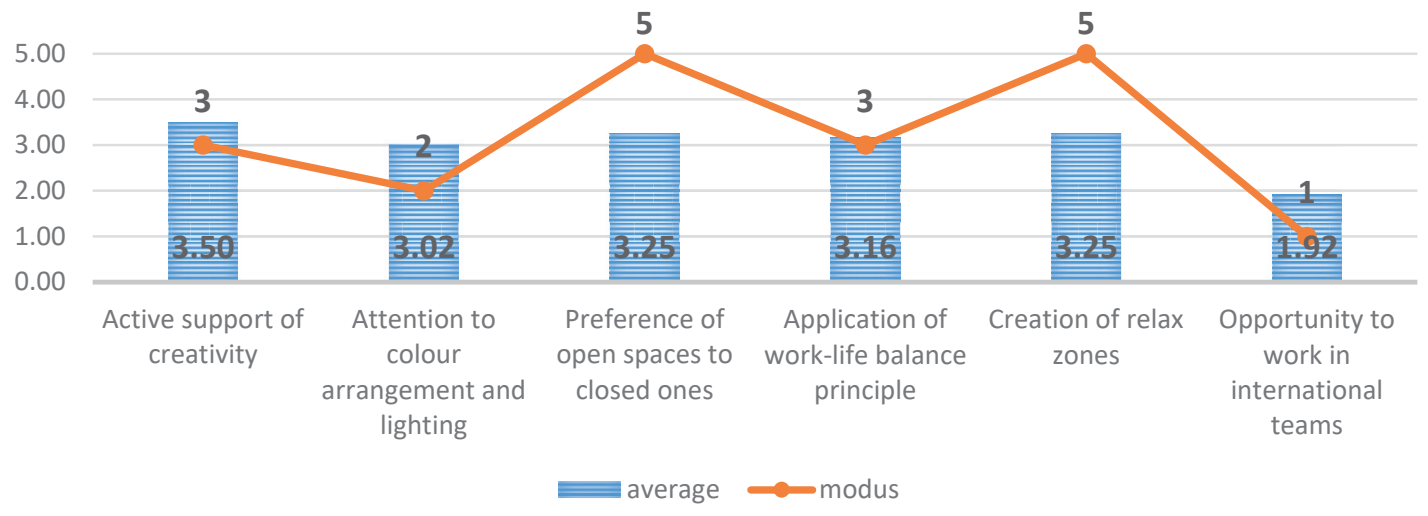

2: Characteristics of a position evaluating creativity and work environment of employees

Source: own elaboration 
is mostly about creative attitude which brings new ideas, seeks differences and new unconventional approaches to solutions of the tasks (Papula, Papulová, 2016).

Another section of questions in the questionnaire contained questions intentionally focused on monitoring and implementing new trends in creativity support of employees and adjustment of work environment to employees - to feel needed, motivated, committed and to make them perform their best.

Managers of food businesses in Slovakia who were the respondents, expressed their level of approval or disapproval within six statements.

Average and the most common answers recorded, are shown in the Fig. 2. The bar graph represents average answers of respondents (data is shown in the basis of the graph) and a line graph shows the most common answers of respondents (data is shown above the graph).

The statement "In the company we try to provide active support of creativity of employees" gained average answer of 3.5 and the most common answer with value of 3 "I rather agree than disagree", which was expressed by $31.13 \%$ of company representatives. Absolute approval was expressed by $22.96 \%$ and absolute disapproval was expressed by $5.52 \%$ of companies.

The average answer to the statement " $A$ huge attention is paid to colour arrangement and lighting of workplace" was neutral, the most common answer reached the value 2 - partial disapproval - 26.71\% of company representatives. Absolute approval was expressed by $17.44 \%$ and absolute disapproval was expressed by $12.14 \%$ of companies.

Big difference in average and most common answer can be seen in the answer to the statement "In the company we prefer working in an open environment to working in closed offices". The average answer was neutral and reached value of 3.25. The respondents often marked the answer absolutely agree (5). Up to $26.49 \%$ of respondents answered so and $15.45 \%$ of companies absolutely disagreed.

The average answer expressing level of approval with the statement "In the company we apply principle of work-life balance = balance between working time and free time activities" was evaluated as neutral (3.16). The most common answer was also neutral (3) - I rather agree than disagree and this was the answer of $40 \%$ of companies. Around $11.48 \%$ absolutely agreed and $15.89 \%$ of companies absolutely disagreed. The answers to clear statements were not so clear at all.

Another significant difference in average and the most common answer was within the statement "Employees are provided with relax zones in the company". Average answer was 3.25 and the most common was 5 - I absolutely agree. The value 5 as absolute agreement was expressed by $26.49 \%$ of respondents and the answer 1 was selected by $13.25 \%$.

The statement "Employees have opportunity to work in international teams" reached average answer of 1.92 and the most common value was 1, expressing absolute disapproval $(60.71 \%$ of company representatives), $13.91 \%$ of respondents partially disagreed. From the mentioned above it is clear that up to a $3 / 4$ of companies (74.62\%) do not provide employees with possibility to work in international teams at all.

The realized Kruskal-Wallis test proved, whether there are dependences between answers of respondents based on size of company, legal form of business, capital share of company and region where the company operates. The results of Kruskal-Wallis test for questions from the fifth section are given in the Tab. II. Values marked “*” represent statistically significant differences on the significance level of 95\% ( $\alpha=0.05)$ and values marked “**” represent highly statistically significant differences on the significance level of $99 \%(\alpha=0.01)$.

Active support of creativity of employees is influenced by region where the company operates. As we can see from the Tab. III, the value of this factor is 0.0367 which is lower than $a=0.05$ and therefore it represents existence of statistically significant differences among the answers of companies from different regions. Size of company, legal form of business and capital share of company do not influence active support of employees' creativity.

Same like with the previous question, paying attention to colour arrangement and lighting from

III: Results of Kruskal-Wallis test - creativity and work environment of employees

\begin{tabular}{lcccc}
\hline & \multicolumn{4}{c}{ Values of Kruskal-Wallis test according to } \\
\hline & $\begin{array}{c}\text { Size } \\
\text { of company }\end{array}$ & $\begin{array}{c}\text { Legal form } \\
\text { of business }\end{array}$ & $\begin{array}{c}\text { Company } \\
\text { capital share }\end{array}$ & Region \\
\hline Active support of creativity & 0.3181 & 0.7759 & 0.2530 & $0.0367^{*}$ \\
Attention to colour arrangement and lighting & 0.1573 & 0.6828 & 0.3128 & $0.0051^{* *}$ \\
Preference of open spaces to closed ones & $<0.0001^{* *}$ & $0.0452^{*}$ & 0.2047 & 0.1737 \\
Application of work-life balance principle & $0.0006^{* *}$ & 0.5215 & 0.2516 & 0.1843 \\
Creation of relax zones & $<0.0001^{* *}$ & 0.7945 & 0.6059 & 0.5050 \\
Opportunity to work in an international team & $<0.0001^{* *}$ & $0.0034^{* *}$ & $<0.0001^{* *}$ & $<0.0001^{* *}$ \\
\hline
\end{tabular}

Source: own elaboration 
the managerial point of view is influenced only by the region where the company operates. However, the value 0.0051 is lower than $a=0.01$, thus they are highly statistically significant differences in the answers of the respondents. Size of company, legal form of business and capital share of company do not influence paying attention to colour arrangement and lighting of work environment.

In case of preference of open spaces to closed ones we can see lower value as for the size of company 0.0001, meaning that there is existence of highly statistically significant differences on the significance level of 99\%. As for the legal form of business we can see the value of 0.0452, representing existence of statistically significant differences on the significance level of 95\%. Thus, we can state that size of company and legal form of business influence preference of open space to closed ones and at the same time, capital share of company and region where the company operates does not influence the preference.

Size of company has influence only on work-life balance application. As for the size of company the value is 0.0006 , representing existence of highly statistically significant differences in answers. However, legal form of business, capital share of business and region where company operates do not influence application of principle work-life balance in a company.

Creating relax zones in companies is also influenced only by size of company, because value $<0.0001$ is lower than $a=0.01$ and therefore it is highly statistically significant differences in answers of respondents. Legal form of business, capital share of business and region where company operates do not influence creating relax zones in companies.

In case of providing opportunities to work in international teams we can see in all the factors values of Kruskal-Wallis test which are lower than alpha $=0.01$ and therefore within all the factors there are highly statistically significant differences in answers of respondents. It means that size of company, legal form of business and capital share of company as well as region where the company operates have significant influence on providing opportunities to work in international teams.

To find out power of dependence among answers we again found value of Spearman correlation coefficient. The highest recorded correlation has a value of 0.36665 and it is highly statistically significant. It represents medium to essential positive dependence between active support of creativity of employees and paying attention to colour arrangement and lighting of work environment. Except for this, we found two other, medium to essential dependences and nine highly statistically significant correlations which belong to the category of low to medium dependences and the remaining three of them are not statistically significant.

\section{Verification of the Given Statistical Assumptions}

Within "Materials and Methods" we formulated research assumptions. Based on the given analysis, they were verified and the results are as follows:

- Communication and motivation

A1: We suppose that companies perceiving communication as inevitable assumption of cooperation in the company as well as outside, have clearly set up rules of employees' motivation.

Research assumption was based on the given value of mutual correlation accepted. Companies, for which communication is inevitable assumption of cooperation in a company and outside have clearly set up rules for employees' motivation. Within both statements respondents mostly marked option "I absolutely agree".

- Creativity and work environment

A2: We suppose that companies supporting employees' creativity pay attention to work environment and apply work-life balance principles. Research assumption was partially accepted. Based on the given characteristics of positions we can state that companies have neutral attitude to support of employees' creativity, work-life balance principle application as well as to work environment (they most often marked answer with value "3"). From the information given we can state that companies support creativity of their employees, pay attention to colour arrangement and lighting of workplace and apply work-life balance principles on workplace. There was, on the other hand, recorded weak statistically significant dependence in relationship of support of employees' creativity and creating relax zones.

\section{DISCUSSION}

To reach coordinated results, well working communication is important (Szarková, 2018). Constantin and Baias (2015) agrees with the statement and adds, that relationships on workplace and outside really depend on managers' communication and overall internal communication. Mutual communication is important because management can therefore inform employees about individual areas of company policy and company plans and employees can react to intentions and steps of the management.

Solving the issue of communication within food businesses in Slovakia we resulted in the same conclusions. The companies consider communication as inevitable and important attribute of mutual cooperation in the company and outside, which was expressed by $85 \%$ of respondents.

Food businesses in Slovakia have, according to the research, clearly set up rules of motivation for employees. The findings agree with the result of the research of authors Vetráková and Mazúchová (2015), that creation of motivation programs, which 
clearly define rules of motivation, belong to the most motivating factors of employees. Employees' motivation in food businesses in Slovakia, is realized especially by material stimulus, using non-material stimulus was marked as neutral. The research of the author Šuteková (2012) confirmed, that the most significant factor influencing interest in work, is the nature of work itself, possibility to develop own skills and learn something new. She also found out, that work environment and human relations are significantly determining factors of motivation and dissatisfaction was fel by employees especially with regards to their salary, possibilities of career development and to benefits. It is inevitable for the managers of companies, to proceed to active creation of motivation programs and plans and to consult with the employees, the possible methods and forms of how the situation within motivation could be improved so that both sides are satisfied and fluctuation of employees decreases.

Based on scientific publication of collective of authors Lušňáková et al. (2019), food businesses in Slovakia show significant potential in the area of implementation of innovations and support of creativity of their employees. Even the research of authors Papula, Papulová (2013) in selected companies in Slovakia confirmed positive attitude of managers to support of creativity of employees as well as to understanding the significance of creativity, within its support at individual employees as well as at the development of competitive advantage and strategic direction of the whole company. Most employees see and appreciates support of their creativity and possibility to be creative. Employees of the selected companies perceive it as fulfilling and stimulating within work. The fact that they get a space to apply their own creativity, is satisfying and pleasing them. It is therefore inevitable for the management of a company, to try to actively support employees' creativity and to create adequate work environment. Employees will appreciate it. On the other hand, our research within food businesses in Slovakia showed neutral attitude of companies to the question of active support of creativity of their employees. Monitoring trends and the right preparation for these trends enable the company to obtain competitive advantage. Sustainability of the market position without innovations and creativity is not possible (Lušňáková, 2019). Even the employees of the selected companies appreciate support of their creativity from the management. The fact that they get space to apply their own creativity, makes them more satisfied and happier.

The selected companies within our research expressed neutral attitude even to the question whether they pay attention to colour arrangement and lighting of workplace. The author Tzempelikos (2017) states that employer must pay a huge attention to workplace so it is not too noisy, dusty, it must have a lot of light, light walls, fresh air, temperature, chill, humidity, good air flow, microclimate.

Analysed companies expressed neutral attitude to application of work-life balance principles and freetime of employees. The need for a change of neutral attitude to highly interested confirms the research of authors Beauregard and Henry (2009), who say that application of work-life balance principle can significantly influence efficiency and productivity of organization and save costs. It also positively influences and empowers social sphere.

Competitive advantage of companies could be sustainability of work force, decreased fluctuation of employees, necessary training with positive impact on the whole efficiency of the company. Top management must intentionally monitor and implement new trends in work with human resources in international corporations. This might help employees to be more quality and attractive human resources in the future (Lušňáková, 2018).

\section{CONCLUSION}

Food businesses in Slovakia based on our findings are in a bad position of human resources. We can state that an effort of companies to understand importance of implementation of new trends in human resource management as well as realization in the practice, is extraordinary. Food businesses in Slovakia showed significant shortcomings within practical application of new trends in human resource management. Many respondents realize the niche and they are determined to eliminate them, others are sceptical and they are happy with what they already know (or do not know) and some of them use excuses like lack of time, money, personnel and other factors.

If a company wants to work effectively, the investment into planning, recruitment, development and sustainability of quality employees, is the cleverest decision.

Therefore, resulting from the findings of the analysis of using new trends in human resource management in food businesses in Slovakia, we recommend the companies to:

- preserve, keep and support personal and direct communication face to face at maximum level possible, to plan regular meetings on workplace and outside, to listen and ask,

- make communication more efficient by implementation of modern information-communication technologies with the aim of quick transfer of information, flexible and early reaction to various situations, 
- elaborate and regularly update motivation plan and motivation program for various groups of employees or individuals, to ensure clear rules and processes and objectivity f evaluation,

- consider active non-material stimulus which especially within qualified employees and professionals, can be stronger motivators than non-material stimulus,

- within innovation management and work conditions as well as nature of employee's work, try to support and develop creativity of employees, apply and evaluate their contribution for the company to make them feel needed and committed,

- in effort to ensure balance between personal and professional life of employees, to communicate and elaborate a system which would meet the requirements of both, the employee and the employer,

- ensure adequate and safe work environment for employees with regards to labour intensity and expected performance, or to communicate and arrange needs, expectations of both interested sides,

- set the rules of flexibility of working time and place of work for employee and to ensure control of fulfilled tasks,

- provide employees with possibility to work in teams, in the area of other organization, in another country, which may help to develop their personality, knowledge, skills and consequently loyalty.

\section{Acknowledgements}

This paper was created within the KEGA project Theory and practice of human resources management and managerial work. Project registration number 041SPU-4/2018.

\section{REFERENCES}

ADAME-SANCHEZ, A., GONZÁLEZ-CRUZ, T. and MARTÍNEZ-FUENTES, C. 2016. Are companies implementing policies to reconcile work and private life so that they are beneficial to their employees or for themselves? Journal of Business Research, 69(11): 5519-5523.

BEAUREGARD, T. A. and HENRY, L. C. 2009. Making the link between work-life balance practices and organizational performance. Human Resource Management Review, 19(1): 9-22.

BENDA-PROKEINOVÁ, R. 2014. Statistics in SAS, SAS in statistics [in Slovak: Statistika v SAS-e, SAS $v$ štatistike]. Nitra: ASPA.

CONSTANTIN, E. C. and BAIAS, C. C. 2015. Employee Voice. Key factor in internal communication. Journal of Procedia- Social and behavioral sciences, 191: 975-978.

KOUBEK, J. 2007. Personnel work in small and medium enterprises [in Czech: Personální práce v malých a stredních firmách]. Praha: Grada Publishing, a.s.

LUŠŇÁKOVÁ, Z., JURIČCOVÁ, Z., ŠAJBIDOROVÁ, M. and LENČÉŠOVÁ, S. 2018. Trends in work with human resources in Slovak agricultural enterprises. In: International scientific days 2018. Praha: Wolters Kluwer ČR, pp. 1253-1264.

LUŠŇÁKOVÁ, Z., JURÍČKOVÁ, Z., ŠAJBIDOROVÁ, M. and LENČÉŠOVÁ, S. 2019. Employees' Creativity Development within Innovative Processes of Enterprise. Scientific Annals of Economics and Business, 66(1): 85-100.

MARKECHOVÁ, D., STEHLÍKOVÁ, B. and TIRPÁKOVÁ, A. 2011. Statistical methods and their applications [in Slovak: Štatistické metódy a ich aplikácie]. Nitra: Univerzita Konštantína Filozofa.

PAPULA, J. and PAPULOVÁ, Z. 2016. Managerial decision-making [in Slovak: Manažérske rozhodovanie]. Bratislava: Kartprint.

PAPULOVÁ, Z. and PAPULA, J. 2013. Creativity and innovation as actual imperative of companies' strategy [in Slovak: Kreativita a inovácie ako aktuálny imperatív stratégií podnikov]. In: Trendy v podnikání 2013. Plzeň: Západočeská univerzita v Plzni.

PINDROCHOVA, M. 2015. Labour law in a nutshell [in Slovak: Pracovné právo v malíčku]. Košice: Alert POLÁČEK, M. 2016. Communication skills as competitive advantage of sales people [in Slovak: Komunikačné zručnosti ako konkurenčná výhoda predajcov]. In: The agri-food value chain: challenges for natural resources management and society. Nitra: SPU, pp. 186-193.

PROKEINOVÁ, R. 2010. Usage of SAS as a tool of quantitative analysis in a questionnaire [in Slovak: Využitie SASu ako nástroja kvantitatívnych analýz v dotazníkovom prieskume]. In: $13^{\text {th }}$ SAS Technology Forum 2010. 20. ledna 2010, Praha. Bratislava: SAS Institute GmbH.

RIMARČÍK, M. 2007. Statistics for practice [in Slovak: Štatistika pre prax]. Košice: Marián Rimarčík.

RUCK, K. 2015. Exploring Internal Communication: Towards Informed Employee Voice. Surrey: Gower publishing limited. 
SHAO, Y., NIJSTAD, A. B. and TAUBER, S. 2019. Creativity under workload pressure and integrative complexity: The double-edged sword of paradoxical leadership. Organizational Behavior and Human Decision Processes, 155: 7-19.

SZARKOVÁ, M. 2018. Communication in management [in Slovak: Komunikácia v manažmente]. Bratislava: Wolters Kluwer.

ŠIMONOVÁ, K. and ŠAFRÁNKOVÁ, J. 2015. Work-life balances a rediscovered modern trend in HR management. Sociálno-ekonomická revue, 13(4): 62-67.

ŠUTEKOVÁ, H. 2012. Analysis of motivation preferences of employees in a selected company [in Slovak: Analýza motivačných preferencií zamestnancov vo vybranom podniku]. Acta Academica Karviniensia, 12(3): 151-160.

TZEMPELIKOS, A. 2017. Editorial: Advances on daylighting and visual comfort research. Building and environment, 113: 1-4.

VETRÁKOVÁ, M. and MAZÚCHOVÁ, L'. 2015. Modelling of Process Work Motivation in Hotels. Procedia Economics and Finance, 34: 508-513.

Zuzana Lušňáková: zuzana.lusnakova@uniag.sk

Silvia Lenčéšová: lencesova.silvia@gmail.com

Veronika Hrdá: veronika.hrda@uniag.sk

Mária Šajbidorová: maria.sajbidorova@uniag.sk 